\title{
Research on the Value and Cultivation Path of Sports Spirit in the Construction of College Campus Culture
}

\author{
Fan Zhang \\ Department of Police Skills and Tactics \\ Nanjing Forest Police College \\ Nanjing 210023, China
}

\begin{abstract}
By using the method of documentation, this paper explores the problems existing in campus culture of universities in the new era. The research holds that the invasion and growing of grey or even black campus culture not only destroys the purity, elegance, ideological spirit, positive enterprising spirit and all kinds of virtues of campus culture, but also directly leads to the encroachment of sports spirit and the large-scale decline of college students' physique. It is suggested that by organizing sports entertainment, sports competitions and sports arts, which are popular among college students, they can learn, feel and cultivate elegant and positive life interest, which will have a good help and leading role in reshaping campus culture, sports spirit and cultivating talents with all-round development.
\end{abstract}

Keywords—sports spirit; sports value; college; campus culture; culture construction

\section{INTRODUCTION}

In the current era and international environment, all kinds of gray culture and even black culture invade the University campus, and grow rapidly in various ways. To a certain extent, it has a very serious negative impact on the university campus culture, and even has a greater destructive and impact. "Campus sports culture is the inheritance and accumulation of university's inherent sports material and sports spirit"[1]. Because of its comprehensive function of group, exterior, passion, team honor incentive and self-challenge, it has become the most dynamic, cohesive and explosive positive energy cultural nutrition in university campus culture. Therefore, it is extremely urgent to optimize, integrate and reshape the current campus culture with sports spirit.

\section{CURRENT PROBLEMS IN CAMPUS CUlture OF CHINESE COLLEGE}

\section{A. The phenomenon of irrational comparison is serious}

Comparing behavior on campus is the most common and serious phenomenon at present. By comparing the price of clothes, bags, mobile phones and computers, brand awareness, and the number of items that individuals have "eliminated", students have formed a deformed view of consumption, values and life. Some students usually show no love in use and no value in thought, in order to show their generosity, wealth and personality.

\section{B. Underground trading flourishes}

Underground transactions, such as class transactions, homework transactions, labor transactions (such as buying meals, washing clothes, receiving and dispatching couriers) and so on, although some students get certain remuneration for their work, after all, few students are willing to work, but more and more are served. As a result, they have developed the mental habits and spiritual dependence of laziness, dislike of learning, ambiguity of ideals and insufficient motivation for struggle, resulting in a vicious circle of learning and personal growth dilemma

\section{Overdraft consumption is popular}

At present, many college students have overdraft behavior, such as credit card consumption, campus loan consumption, and overdraft behavior among students, which is the most negative and bad phenomenon in campus culture [2]. Especially because of excessive borrowing, very few students have seriously distorted their moral outlook and values. They face good students with a rogue mentality. The most controversial and negative impact is the phenomenon of bare loans for girls, which makes the original campus as a pure land covered with luxury and pornographic dust.

\section{Three Kinds of gambling surge}

There are three kinds of gambling in universities: one is on-the-spot gambling among students. A small number of students gather to play cards and mahjong, which is between amateur entertainment and gambling. Without causing malignant incidents, they are in a latent state. The second is online gambling. With gambling, gambling and all kinds of online gambling games as the main part, the phenomenon of college students jumping to suicide in the past reflects that the negative impact on the students involved is enormous, and even changes their life trajectory. Third, all kinds of red envelope games. With the support of social software such as Wechat Friends Circle and QQ Group, students who lack judgment and seek stimulation often have deviations in their values. 


\section{THE ROLE OF SPORTS SPIRIT IN RESHAPING CAMPUS CUlture of Chinese COLlEGE}

As an organic part of the connotation of College campus culture, sports spirit plays a positive and practical role in precipitating, integrating and refining College campus culture by forming enlightening values in the process of physical exercise.

\section{A. Cultivate the Spirit of Struggle and Enterpreneur}

As the future of the motherland and the hope of the nation, college students possess and constantly exert the spirit of struggle and enterprising, which is not only one of the basic qualities of their professional growth, career development and career development, but also one of the most powerful, driving and stimulating elements of campus culture. Based on the various problems exposed by the current campus culture, there are three ways to put them into practice:

First is to use sports activities to cultivate the quality of hardship and endurance. Because of the overall economic development situation in China and the prosperity of the economic conditions of most college students' individual families, their living and growing environment is relatively superior and even "respectful" and lack of hardworking spirit and endurance quality, which has become one of the common characteristics of most college students and one of the negative phenomena in the campus culture. Guiding college students to participate in middle-distance running, crosscountry running, obstacle running, rock climbing and body flexibility training activities, so that they can recognize and understand the life experience in the positive physical and mental experience. Only by cultivating and constantly improving the quality of hardship and endurance can we flexibly cope with various difficulties encountered in the development of life, occupation and career.

The second is to use sports activities to cultivate selfchallenge spirit. Life is always full of challenges, not only caused by objective factors such as environment and system, but also by factors such as family, emotional and physical health. On the basis of constantly improving bad habits of life, study and work, students are educated by various sports to develop professional challenges, physical limit challenges and other self-challenge awareness and ability. Make it able to meet all kinds of challenges with healthy psychology, scientific cognition and healthy body, and make full psychological, ideological and physical preparations for the happiness of life and career development.

Third, the use of sports activities to cultivate the quality of perseverance. "Persistence" is one of the qualities that contemporary college students lack. The use of various projects to cultivate college students' perseverance in pursuit of correct goals and perseverance in the face of various difficulties, so that they can persevere in the end not to give up, to overcome various difficulties with strong will, to solve various problems, and to achieve their own life goals and career ideals.

\section{B. Develop Team Cooperation Awareness}

The widespread use of modern intelligent facilities, with smart phones, laptops, tablets and iPads as the standard configuration, facilitates college students' study, life and amateur entertainment, while limiting it to the narrow space of self-entertainment and self-entertainment based on the network platform. As a result, the reality of College Students' personality and the division of the network have become typical common and explicit characteristics, such as selfishness, isolation and difficulty in cooperation.

There are two solutions: one is to use group projects to cultivate the sense of skill cooperation. With basketball, football, volleyball, tennis and various group dances, we can cultivate college students' sense of role and skill cooperation in sports, such as the role of forward and guard in basketball activities. In the struggle of mutual cooperation and winning goal, it can consciously proceed from the reality of personal strength and skills, cultivate and improve the consciousness of complement and tacit understanding of skills in project technical requirements, and transform and integrate into the consciousness and basic ideological quality of College students. The second is to use the atmosphere of group activities to cultivate the sense of interpersonal cooperation. Make full use of the specific space-time characteristics of sports activities, such as the concentration of the crowd, the established location, the specific activity space of project diversity, to create a sports culture atmosphere of mutual promotion, mutual learning and mutual help for college students. In a positive and passionate sports culture environment, it can receive the influence of sports spirit. For example, the exhibition and performance of bodybuilding figure can cultivate the appreciation consciousness of others, the coordination ability of interpersonal relationships, the interest of multi-project learning and sports, etc.

\section{Cultivate Beautiful Life Interest}

Creating beauty and having positive and enterprising aesthetic ability are the basic qualities of College students. "Beauty" as the crystallization of sports culture and spirit, through the way of "improving physical fitness" and "activating campus culture atmosphere", the role of "improving students' aesthetic and life interest" is "the main function of campus sports culture construction in Colleges and universities" [3]. Therefore, there are three ways to improve and promote campus culture with the power of sports beauty: one is to create a healthy cultural atmosphere of sports. Fully activating and utilizing the "love of beauty" of College students, so that they can learn and carry out professional bodybuilding sports activities in their own bodybuilding activities, and create personalized bodybuilding sports skills.

On the one hand, to create a general physical fitness atmosphere, such as body coordination, posture, temperament, etc. First, college students participate in Aerobics activities, forming a positive atmosphere with beauty, thus attracting more students to carry out aerobics, aerobics dance and other aerobics activities. The second is to cultivate the elegant interest of appreciating sports beauty. Create and use various carriers to guide students from excessive network activities, unhealthy entertainment activities, and other gray activities, 
and guide them to discover the beauty of strength, speed and shape in the process of enjoying various sports and competitive activities. Third, the use of fashion sports to cultivate healthy fashion concept. Represented by the popular yoga, belly dance, steel pipe dance, parkour, hip-hop dance and other projects, college students gradually establish the fashion concept of health, environmental protection and health preservation in the process of viewing, learning and experiencing.

\section{Cultivate Rule Awareness and Competition Awareness}

By using the rules and standards of various sports events and their competitive forms, we can cultivate college students' awareness of abiding by laws and regulations, College rules and regulations, and make them become law-abiding and competitive young people. There are two modes of operation: one is to hold campus games.

With the College comprehensive sports meeting, football match and basketball match every semester or year in Colleges and universities, the role of athletes, cheerleaders, waiters and referees should be involved. In the due diligence of various positions and in the struggle competition of athletes, the generation education of sports spirit should be achieved through personal experience. The second is to organize sports activities with College characteristics. With a variety of special interesting sports activities, such as fancy basketball, three-man football, martial arts competitions, as well as various sports games. So that college students can not only experience the pleasure of sports activities themselves, but also accept physical fitness and other aspects of the test and exercise, sports skills learning and application, sports interest training and specialty development unified.

\section{WAYS TO PROMOTE SPORTS SPIRIT AND REBUILD COLlege CAMPus Culture}

To create the sports spirit carrier that college students like and operate well is to use the way of "sports system culture construction, sports spirit culture construction" to realize the development and pursuit of campus culture [4].

\section{A. Physical Fitness Activities}

In accordance with the regulations and requirements of the Ministry of Education and the General Administration of Sports for the development of College Students' physical health, physical fitness activities are organized and carried out to support college students' daily sports activities in order to enrich and enhance the connotation of campus culture [5]. There are three kinds of routine activity carriers:

First, morning running activities, that is, morning running activities after getting up in the morning and before breakfast. According to the requirements of the College, the students complete the required distance running. In order to cultivate college students' sports habits, fitness habits and scientific awareness of health, their high spirits, healthy physique and active fitness atmosphere, condensed into a positive, striving and pursuing campus cultural form [6].

Second, broadcast gymnastics. College students carry out radio Gymnastics during class so that they can stretch their muscles and bones, exercise their strength and maintain their vitality in the lively and passionate gymnastics.

Third, the independent movement after class. Every weekday afternoon after College, such as badminton, football, basketball, tennis activities, as long as students can operate, convenient, like and familiar with, they can master the actual activities according to their own time, place and equipment [7]

\section{B. Sports Art Activities}

Taking the crystallization of sports and arts such as yoga, hip-hop dance, belly dance, steel pipe dance and bodybuilding dance as representative projects, it creates diversified, pluralistic and inspiring sports cultural forms and sports spirit performance for college students. The beauty and charm of sports art can effectively realize the education of sports skills, art and sports culture. There are two carriers of suggestion operation:

First is sports art learning behavior. With interest groups, associations and specialist counseling classes of various sports and arts projects as carriers, college students are guided by professional teachers, coaches, specialists and amateurs of the projects. To cultivate more students who are interested in sports and art projects, to form the core radiation source of sports spirit in their continuous learning activities, to do a good job of example and skill education for other students, and to give full play to the role of cultural education and environmental education [8]

The second is the performance of sports art. The organizational form of sports art performance can be divided into three kinds: the first is the performance program of cultural and recreational activities. Through the performance activities of excellent actors, set an example for other students and show the charm of sports and art projects. The second is the comprehensive performance of various sports and arts. To arrange various forms of sports art so that students can understand, learn and master more forms of sports art activities in the performance and appreciation of diverse sports art projects, and to inspire students with various physical conditions, sports abilities and sports awareness to do well in sports activities and daily fitness [9].

Third, sports and art competitions. For example, square dance performance competition, sports dance competition and aerobics competition between classes, grades and departments can stimulate college students' enthusiasm and creativity in learning sports art, innovating sports art and using sports art.

\section{Sports Competitive Activities}

The organizational effectiveness of sports competitions includes three categories:

The first is the National College Games and the provincial College Games. This is the national carrier of purifying and promoting campus culture [10]. It takes College honor and local government honor as incentives to lead Colleges and students to develop appropriate sports and innovate campus culture.

Second, the inter-university friendship games between the universities in the same city. Under the organization and 
coordination of the same city government, or under the cooperation mechanism with the resident universities, we should carry out comprehensive or several sports activities, and use the spirit of sports to build the urban campus culture.

Third, all kinds of campus games. For example, Collegewide, faculty-based, disciplinary and even interesting campus games, so that students in the practice of various sports spiritual elements, in various forms to enrich the campus culture.

\section{CONCLUSION}

Sports culture is an important part of campus culture in Colleges and universities. It is also a very important potential and hidden curriculum in Higher Education in China. As the most passionate, beautiful and inspiring inner accomplishment, sports spirit can effectively enrich, purify and enhance the connotation of campus culture. It also provides students with a pure land, which has a direct, efficient and profound effect on the education and improvement of College Students' bad habits. In the course of active interaction, cooperation and support, college students can get pressure release, physical training, psychological education and knowledge education, and integrate morality, intelligence, physical fitness, beauty, labor, professional ideal and life ideal.

\section{ACKNOWLEDGMENT}

This work was supported in part by the MOE Layout Foundation of Humanities and Social Sciences under Grant 19YJA890037.

In part by the Project of China Postdoctoral Science Foundation under Grant 2019T120441 \& 2017M611849.

In part by the Project of the Fundamental Research Funds for the Central Universities under Grant LGZD201805.

In part by the 13th Five-Year plan project of Jiangsu Education Science under Grant C-c/2018/01/11.

In part by Jiangsu Qing Lan Project under Grant 2017.

In part by Pre-research project of Nanjing Forest police College under Grant LGY201603.

In part by Nanjing Forest police College Teaching Reform Project under Grant ZD18104.

In part by Overseas Research and Study Project of Excellent Young and Middle-aged Teachers in Colleges and Universities of Jiangsu Province of 2018.

\section{REFERENCES}

[1] Cai Jian-guang, Zhang Tie-xiong, "Physical Culture Promoting Campus Culture : From the Perspective of Building China into a Powerful Country with Culture," Journal of Hunan University of Science \& Technology, vol. 18, pp. 1-3, July 2015. (In Chinese)

[2] Ding Zhao-xiong, "Perspective on life education in physical education curriculum," Journal of physical education, vol. 15, pp. 70-74, September 2008. (In Chinese)

[3] Li Zhi-xia, Li Zhi-hong, "Consideration on the Influence of College Campus Sport Culture Construction to Students Daily Sport Life," Bulletin of Sport Science \& Technology, vol. 25, pp. 136-138, July 2017. (In Chinese)

[4] Dan Yan-fang, Li Xin-ke, Chen Qing, "Physical education: the return of the origin of life education, "Journal of Wuhan Institute of Physical Education, vol. 42, pp. 78-81, April 2008. (In Chinese)

[5] Duan Li-mei, Dai Guo-bin, "A new view of the logical starting point of physical education from the perspective of 'whole person' life education,” China Sport Science, vol. 35, pp. 78-82, July 2015. (In Chinese)

[6] Wang Zi-pu, Sun Xue-ming, "The Construction of Life Safety Education System in School Physical Education in China," Journal of physical education, vol. 19, pp. 93-95, September 2012. (In Chinese)

[7] XU Wei, "College Campus Sports Culture Construction, Education and Their Internal Mechanisms," Journal of Beijing University of Physical Education, vol. 38, pp. 94-99, January 2015. (In Chinese)

[8] He Tao, "The Construction of Campus Sports Culture Incentive Mechanism and Evaluation System Research," Bulletin of Sport Science \& Technology, vol. 24, pp.120-121, September 2016. (In Chinese)

[9] Wang Fan, Yang Xueqin, Mou Shaohua, et al., "The value of school sports education under the demand of life safety," Journal of physical education, vol. 19, pp. 78-81, May 2012. (In Chinese)

[10] Ran Xue-dong, Deng Chen-liang, "The triple attribute of life education and the reform of school physical education," Journal of Shenyang Institute of Physical Education, vol. 32, pp. 67-69, May 2013. (In Chinese) 